Vol. 31(2):219-229

DOI: 10.4217/OPR.2009.31.2.219

\title{
Note
}

\author{
동중국해 북부해역에서 부유물질과 입자성유기탄소의 \\ 분포 특성 및 연간 변화 \\ 김동선 $^{1 *} \cdot$ 최상화 ${ }^{2} \cdot$ 김경희 $^{1} \cdot$ 김철호 $^{1}$ \\ 1한국해양연구원 기후 - 연안재해연구부 \\ 2한국해양연구원 해양자료팀 \\ (425-600) 경기도 안산시 안산우체국 사서함 29호
}

\section{The Distribution and Interannual Variation in Suspended Solid and Particulate Organic Carbon in the Northern East China Sea}

\author{
Dongseon Kim ${ }^{1 *}$, Sang-Hwa Choi ${ }^{2}$, Kyung Hee Kim ${ }^{1}$, and Cheol-Ho Kim ${ }^{1}$ \\ ${ }^{1}$ Climate Change \& Coastal Disaster Research Department, KORDI \\ ${ }^{2}$ Ocean Data Management Team, KORDI \\ Ansan P.O. Box 29, Seoul 425-600, Korea
}

\begin{abstract}
In order to establish annual variations in the marine ecosystem of the East China Sea, suspended solids (SSs) and particulate organic carbon (POC) were extensively investigated in the northern part of the East China Sea from August 2003 to April 2008. Surface SS concentrations showed large spatial variations in spring and fall, but not in summer. Surface SS concentrations in spring were lower than those in summer and fall. In summer, SSs discharged from Changjiang were mostly deposited in the coastal areas and did not reach our study area which was located about $260 \mathrm{~km}$ from the river mouth. High SS concentrations were observed near the bottom, which resulted from resuspension of bottom sediments by the bottom currents. Surface POC concentrations did not exhibited large seasonal variations. Phytoplankton biomass was a main factor controlling surface POC concentrations. POC/chlorophyll ratios showed large seasonal variations, with maximum numbers in summer. POC/PON ratios were higher in summer than the Redfield ratio (6.6), while they were lower in spring and fall. In summer, higher POC/ chlorophyll and POC/PON ratios were probably attributed to the high phytoplankton mortality caused by nutrient depletion in surface waters.
\end{abstract}

Key words : suspended solid, particulate organic carbon, chlorophyll, northern East China Sea

1. 서 론

동중국해는 서태평양에서 가장 큰 대륙주변해이며 넓은 면적의 대륙붕을 포함하고 있다. 동중국해는 동쪽으로 쿠 로시오 해류와 경계를 이루고 있어 이들 사이에서 경계작 용(frontal process)과 쿠로시오의 저층수가 대륙붕으로 올

\footnotetext{
*Corresponding author. E-mail : dkim@kordi.re.kr
}

라오는 용승작용에 의해 상당한 물질교환이 이루어지는 것으로 알려져 있다(Liu et al. 1992; Chen et al. 1995; Chen and Wang 1999). 또한, 서쪽으로는 중국대륙과 경 계를 이루고 있어 중국대륙으로부터 장강을 통해 많은 양 의 담수와 부유물질이 유입된다. 장강을 통해 동중국해로 배출되는 담수 방류량은 1년에 $924 \mathrm{~km}^{3}$ 이며(Tian et al. 1993), 계절에 따라 큰 변화를 보여 겨울에는 최저 방류량 을 보이고 여름에 최고 방류량을 보인다(Beardsley et al. 
1985). 겨울에는 장강 방류량이 작고 북서풍이 강하게 불 기 때문에 장강 배출수가 중국 해안선을 따라 남쪽으로 작은 범위로 한정되어 영향을 미친다. 하지만 여름에는 많 은 담수 방류량과 남풍에 의해 장강 배출수가 대륙붕을 가로질러 동중국해 북쪽해역에 영향을 미쳐 장강희석수 (Changiiang Diluted Water)가 주요 수괴로 알려져 있다 (Hu 1994; Su and Weng 1994). 동중국해는 전 세계에서 육상기원 쇄설물의 유입이 가장 많은 해역 가운데 하나이 며, 1 년에 $4.8 \times 10^{8}$ 톤의 부유물질이 장강을 통해 동중국해 로 유입되어 주로 장강 하구와 중국대륙의 남서연안에 퇴 적된다(Sternberg et al. 1985; Milliman and Syvitski 1992). 해양에서 많은 물질들이 입자형태로 존재하기 때문에 부유물질은 물질이동에 있어서 매우 중요한 역할을 한다. 연안해역과 대륙붕에서 저층류(bottom current)에 의해 형 성된 혼탁층(turbidity layer)이 자주 관측되며, 이런 혼탁 층은 부유물질의 순환에 상당히 큰 영향을 끼친다. 혼탁층 에 대한 연구는 주로 조류의 영향을 많이 받는 염하구와 만에서 많이 수행되었으며(Kranck and Milligan 1992; Sanford 1993), 동중국해 대륙붕에서도 혼탁층에 대한 연 구가 많이 수행되었다(Matusike et al. 1983; Tanaka et al. 1987; Okamura et al. 1997). Tanaka et al.(1987)은 처음 으로 동중국해 대륙붕 해저면에서 관측된 혼탁류의 분포 를 도시하였다. 대륙붕에서 조류(tidal current)가 혼탁층 형성에 가장 큰 영향을 미치는 것으로 보고되었다 (Matusike et al. 1983; Tsai and Chen 1996). 동중국해에 서 혼탁층에 대한 연구는 많이 수행되었지만, 표층 부유물 질의 분포에 대해서는 거의 연구가 이루어지지 않았다.

입자성유기탄소(particulate organic carbon)는 해양에서 탄소의 생지화학적 순환에 있어서 매우 큰 역할을 한다 (Calson et al. 1994). 대륙주변해는 대양에 비해 일차생산 력이 월등히 높지만 해양 탄소순환에 있어서 대륙주변해 의 역할은 아직까지 명확히 이해되지 못한 상태이다(Liu et al. 2000). Walsh(1991)는 대륙주변해는 전 세계 해양의 $20 \%$ 미만을 차지하지만, 해양 탄소와 질소의 생지화학적 순환에 있어서 대륙주변해의 역할이 대양과 대등하다고 주장하였다. 동중국해는 세계에서 가장 넓은 대륙주변해 가운데 하나이지만 아직까지 입자성유기탄소의 순환이나 분포에 대해서는 잘 알려져 있지 않다.

현재 삼협댐(Three-Gorges Dam)이 장강의 중류지역에 건설 중에 있으며, 2009년에 모든 공사가 완공될 예정이 다. 이 댐이 완공되면 장강을 통해 동중국해로 배출되는 담수와 부유물질의 양이 크게 감소하여 동중국해 해양생 태계에 커다란 영향을 미칠 가능성이 높다(Milliman 1997; Humborg et al. 1997). 최근 연구에 의하면, 2003년 6 월에 삼협댐의 일차 물막이 공사 후에 장강에 인접한 동 중국해에서 공사 전에 비해 일차생산력이 $86 \%$ 가량 감소
하였고 미세조류 군집구조도 변화하였다고 보고하였다 (Gong et al. 2006; Jiao et al. 2007). 또한, 동중국해는 주 로 대륙붕으로 이루어져 있기 때문에 지구온난화에 의한 해양환경 변화가 급격히 일어날 가능성이 높다. 따라서 이 런 인위적인 요인에 의해 동중국해의 해양환경과 생태계 가 어떻게 변화하는지를 파악하기 위해서 장기간 해양관 측이 필요하다.

본 연구는 지구온난화와 삼협댐 건설에 의한 동중국해 해양환경 변화를 파악하기 위해서 장기 해양관측의 일환 으로 수행되었다. 본 논문에서는 2003년부터 2008년까지 여섯 차례 탐사를 통해 동중국해 북부해역에서 관측한 부 유물질과 입자성유기탄소에 대한 결과를 보고하고자 한 다. 본 논문의 목적은 동중국해 북부해역에서 부유물질과 입자성유기탄소의 수평 및 수직분포를 조사하여, 이들의 계절 및 연간 변화를 파악하는 것이다.

\section{2. 재료 및 방법}

현장조사는 한국해양연구원 연구선 이어도호를 이용하 여 봄에 두 차례(2004년 4월 29일 5월 8일, 2008년 4월 14일 24일), 여름에 세 차례(2003년 8월 26일 9월 3일, 2006년 7월 19일 25일, 2007년 7월 18일 27일), 가을에 한 차례(2005년 10월 31일 11월 8일) 등 모두 여섯 차례 수행하였다. 연구 해역은 북위 $31^{\circ} 30^{\prime} \sim 34^{\circ} 00^{\prime}$, 동경 $124^{\circ} 00^{\prime} \sim$ $127^{\circ} 30^{\prime}$ 으로, 주로 동중국해 북부해역이다(Fig. 1). 본 연구 해역의 동경 125 126도 사이에 대마난류(Tsushima Warm Current)와 연안수(Coastal Water)가 경계하는 열염분전선 (thermohaline front)이 존재한다(Hickox et al. 2000). 이 열염분전선을 기준으로 연구해역을 동쪽과 서쪽해역으로 나누었다(Fig. 1). 각 정점 마다 SeaBird CTD(SeaBird 911)를 이용하여 수온과 염분을 측정하였고, 표층에서 해 저면까지 표준수심 $(0,10,20,30,50,75,100 \mathrm{~m})$ 에서 니 스킨(Niskin) 채수기를 이용하여 해수를 채집하였다. 해수 $500 \mathrm{~m} l$ 를 각각 $0.7 \mu \mathrm{m}$ Whatman $\mathrm{GF} / \mathrm{F}$ 여과지로 거른 후 에, $\mathrm{GF} / \mathrm{F}$ 여과지는 부유물질, 입자성유기탄소, 입자성유기 질소, 엽록소 농도 분석을 위해 냉동하였다. 부유물질 농 도는 $\mathrm{GF} / \mathrm{F}$ 여과지를 $60^{\circ} \mathrm{C}$ 에서 24 시간동안 말린 후에 무 게를 측정하여 계산하였다. 입자성유기탄소와 입자성유기 질소 농도는 $\mathrm{GF} / \mathrm{F}$ 여과지(사용 전에 $550^{\circ} \mathrm{C}$ 에서 5 시간 태 움)를 염산 원액이 들어있는 데시케이터에 24시간 동안 넣어 무기탄소를 제거한 후, $\mathrm{CNS}$ 분석기(EA1110, $\mathrm{CE}$ Instrument)를 이용하여 분석하였다. 엽록소 농도는 $90 \%$ 아세톤 $10 \mathrm{~m} /$ 로 24시간 동안 추출한 후 TD-700 fluorometer (excitation filter $436 \mathrm{~nm}$, emission filter $680 \mathrm{~nm}$ )를 이용 하여 측정하였다. Phaeopigment 농도는 아세톤으로 추출 된 엽록소에 $1 \mathrm{~N}$ 염산을 넣고 1 분 30 초 후에 Turner- 


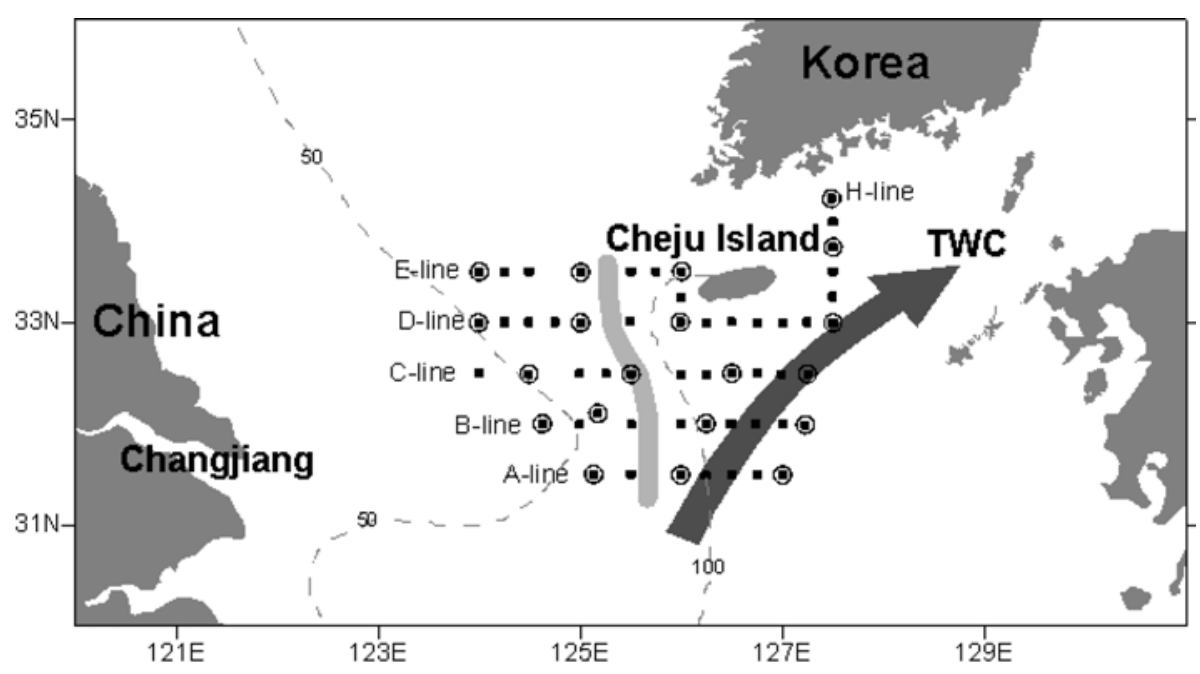

Fig. 1. Study area and sampling stations in the northern East China Sea. Filled squares indicate surface sampling stations, and open circles hydrocasting stations. A thick grey line indicates a thermohaline Front, and TWC is the Tsushima Warm Current.

designed fluorometer로 측정하였다. 본 연구에서는 엽록 소 측정값에서 phaeopigment 농도를 뺀 보정된 엽록소 값 을 이용하였다.

\section{3. 결과 및 토의}

\section{부유물질의 분포 및 계절변화}

동중국해 북부해역에서 관측한 표층 부유물질 농도는 계절에 따라 큰 차이를 나타냈다(Fig. 2). 여름에는 2003 년, 2006년, 2007년 세 차례 관측을 수행하였는데, 해역에
따른 표층 부유물질 농도가 다른 계절에 비해 큰 차이를 나타내지 않았다. 2003년에 관측한 표층 부유물질의 평균 농도는 $13.2 \mathrm{mgl}^{-1}$ 로 가장 낮았고 2007 년에는 $17.0 \mathrm{mg} l^{-1}$ 으로 가장 높았다(Table 1). 2003년 8월에 관측한 표층 부 유물질 농도는 전반적으로 북쪽에서 남쪽으로 갈수록 증 가하는 반면, 2006년 7월과 2007년 7월에는 특징적인 분 포양상을 보이지 않고 연구해역 중앙에서 낮았고 주변에 서 높은 농도를 나타냈다. 연구해역은 여름동안에 장강 유 출수의 영향을 많이 받는 것으로 보고되었다(Kim et al. 2006; 김 등 2007). 2003년과 2006년 여름에는 $30 \mathrm{psu}$ 이
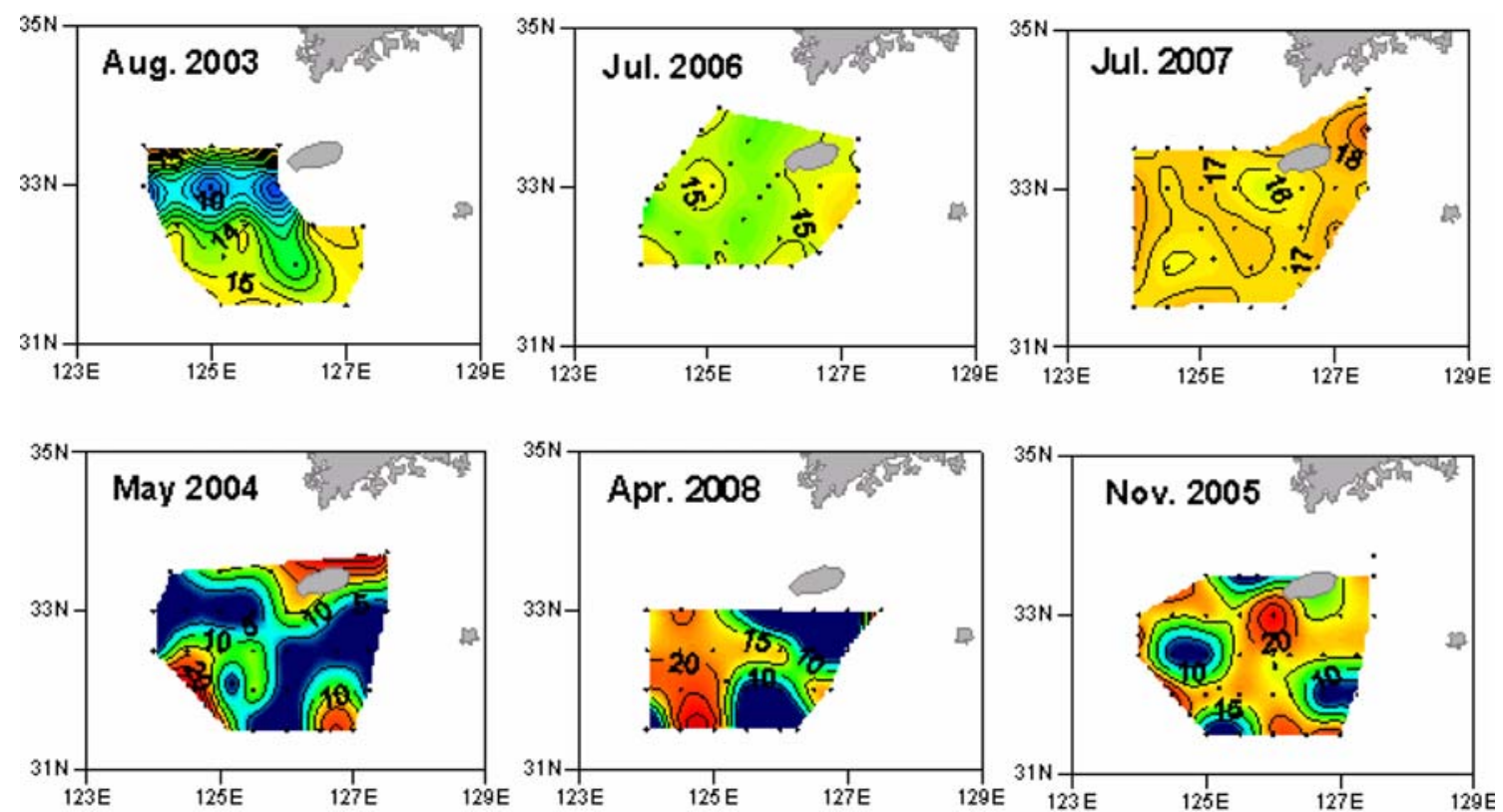

Fig. 2. Surface distribution of suspended solids $\left(\mathrm{mg} l^{-1}\right)$ in the northern East China Sea from August 2003 to April 2008. 

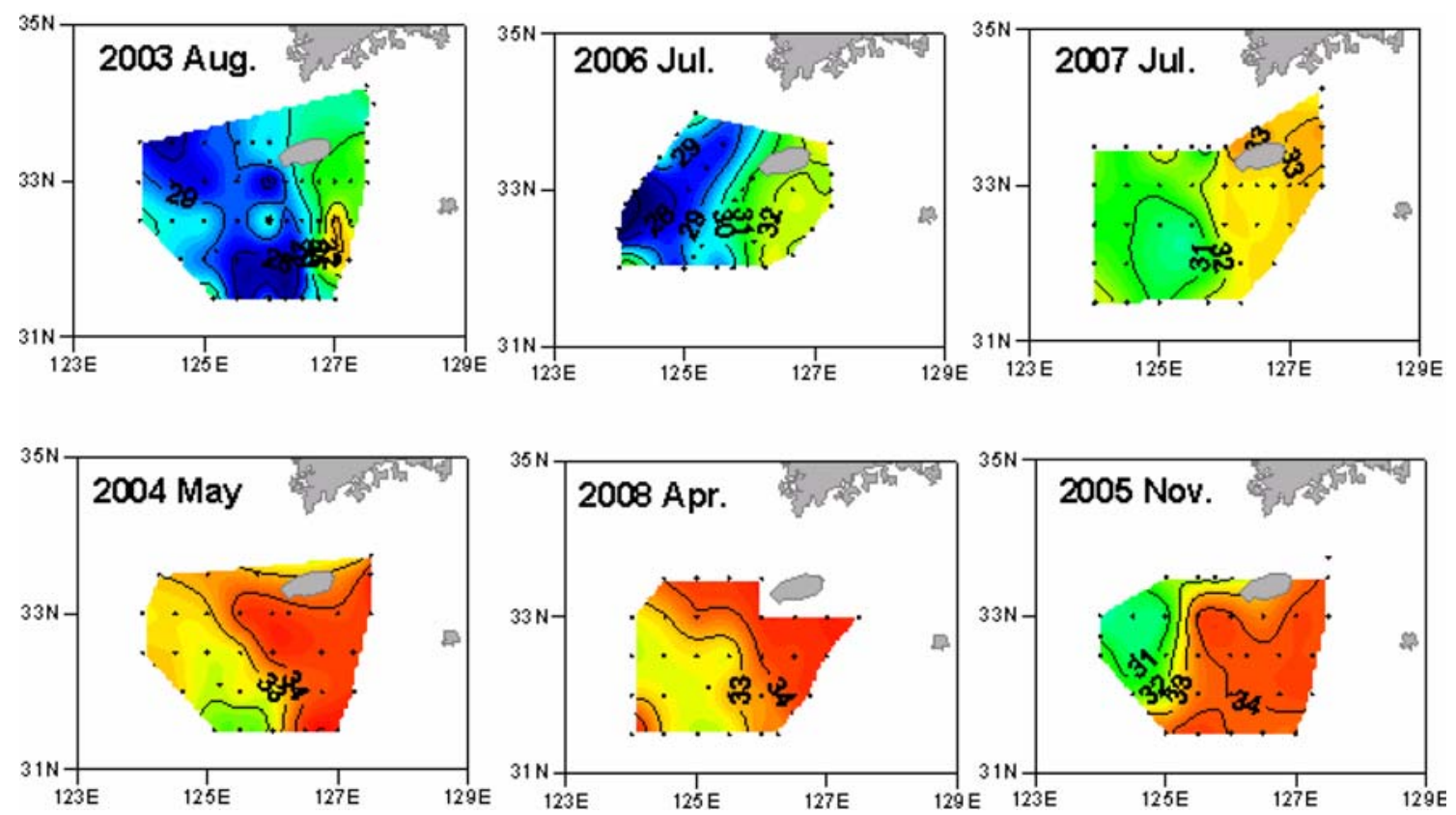

Fig. 3. Surface distribution of salinity in the northern East China Sea from August 2003 to April 2008.

하의 저염수가 장강에 인접한 서쪽해역에서 관측되었지만 2007 년 여름에는 $30 \mathrm{psu}$ 이하의 저염수가 연구해역에서 전혀 관측되지 않았다(Fig. 3). 이렇게 연구해역에서 저염 수가 관측된 것은 장강 유출수가 연구해역으로 유입되었 기 때문이다. 장강을 통해 동중국해로 유입되는 부유물질 의 배출량은 연간 $4.8 \times 10^{8}$ 톤으로, 장강은 동중국해에서 부유물질의 가장 중요한 기원으로 알려져 있다(Milliman and Syvitski 1992). 만약 장강 유출수가 연구해역으로 유 입되었다면 부유물질도 함께 유입되어 부유물질 농도가 증가해야할 것이다. 하지만 장강 유출수의 영향을 많이 받 은 2003년과 2006년에 관측한 표층 부유물질 농도는 장 강 유출수의 영향을 거의 받지 않은 2007년에 관측한 것 보다 오히려 낮았다(Fig. 2). 또한, 2003년과 2006년에도 표층 부유물질 농도는 장강 유출수의 영향을 받은 서쪽해 역보다 장강 유출수의 영향을 받지 않은 동쪽해역에서 오 히려 높게 관측되었다. 이것은 장강을 통해 동중국해로 배 출된 부유물질은 대부분이 장강 인근해역에 퇴적되고 장 강으로부터 $260 \mathrm{~km}$ 가량 떨어져 있는 연구해역까지는 도 달하지 않는다는 것을 지시해 준다.

봄에는 2004년과 2008년 두 차례 관측을 수행하였는 데, 표층 부유물질 농도는 여름과 달리 해역에 따라 큰 차 이를 나타냈다(Fig. 2). 2004년 봄에 관측한 표층 부유물 질 농도는 $0.5 ~ 36.5 \mathrm{mg} l^{-1}$ 의 범위를 보였고 평균 농도는 $8.6 \mathrm{mg} l^{-1}$ 이었으며, 2008 년 봄에는 $0.7 \sim 22.6 \mathrm{mg} l^{-1}$ 의 범 위를 나타냈고 평균 농도는 $11.7 \mathrm{mg} l^{-1}$ 으로 여름에 비해 대체로 낮았다(Table 1). 2004년 봄에는 특징적인 분포양 상을 보이지 않았고 제주도 북쪽해역과 남서해역에서 20
Table 1. Concentrations of suspended solid and particulate organic carbon (POC) in the surface waters from 2003 to 2008

\begin{tabular}{|c|c|c|c|}
\hline Season & Time & $\begin{array}{l}\text { Suspended solid } \\
\quad\left(\mathrm{mg} l^{-1}\right)\end{array}$ & $\begin{array}{c}\text { POC } \\
\left(\mu \mathrm{mol} l^{-1}\right)\end{array}$ \\
\hline \multirow{3}{*}{ Summer } & Aug. 2003 & $\begin{array}{c}7.3-16.4\left(19^{*}\right) \\
\left(13.2 \pm 3.5^{* *}\right)\end{array}$ & $\begin{array}{c}11.3-32.4(19) \\
(19.7 \pm 5.7)\end{array}$ \\
\hline & Jul. 2006 & $\begin{array}{c}11.5-17.3(33) \\
(14.7 \pm 1.1)\end{array}$ & $\begin{array}{c}8.3-41.0(33) \\
(21.2 \pm 10.2)\end{array}$ \\
\hline & Jul. 2007 & $\begin{array}{c}15.0-20.3(33) \\
(17.0 \pm 0.9)\end{array}$ & $\begin{array}{c}5.1-40.8(33) \\
(16.6 \pm 10.9)\end{array}$ \\
\hline \multirow{2}{*}{ Spring } & May 2004 & $\begin{array}{l}0.5-36.5(30) \\
\quad(8.6 \pm 8.5)\end{array}$ & $\begin{array}{c}6.7-52.6(30) \\
(16.8 \pm 8.8)\end{array}$ \\
\hline & Apr. 2008 & $\begin{array}{c}0.7-22.6(26) \\
(11.7 \pm 8.2)\end{array}$ & $\begin{array}{c}8.4-67.3(29) \\
(23.8 \pm 12.8)\end{array}$ \\
\hline Fall & Nov. 2005 & $\begin{array}{c}0.8-30.0(36) \\
(14.7 \pm 7.1)\end{array}$ & $\begin{array}{c}8.3-33.3(36) \\
(17.4 \pm 6.5)\end{array}$ \\
\hline
\end{tabular}

*Parenthesis indicates the number of data.

${ }^{* *}$ Parenthesis indicates the average value and standard deviation.

$\mathrm{mg} l^{-1}$ 이상의 높은 농도를 나타냈다. 2008년 봄에는 표층 부유물질 농도가 전반적으로 서쪽해역에서 높았고 동쪽해 역에서 낮았다. 가을에는 2005년 한 차례 관측을 수행하 였는데, 표층 부유물질 농도는 봄과 유사하게, 해역에 따 라 큰 차이를 나타냈다(Fig. 2). 2005년 가을에 관측한 표 층 부유물질 농도는 $0.8 \sim 30.0 \mathrm{mg} l^{-1}$ 의 범위를 보였고 평 균 농도는 $14.7 \mathrm{mg} l^{-1}$ 으로, 여름에 관측한 값들과 유사하 였고 봄에 관측한 값들보다는 높았다(Table 1). 가을에는 $5.0 \mathrm{mg} l^{-1}$ 이하의 낮은 부유물질 농도가 패치(patch) 형태 

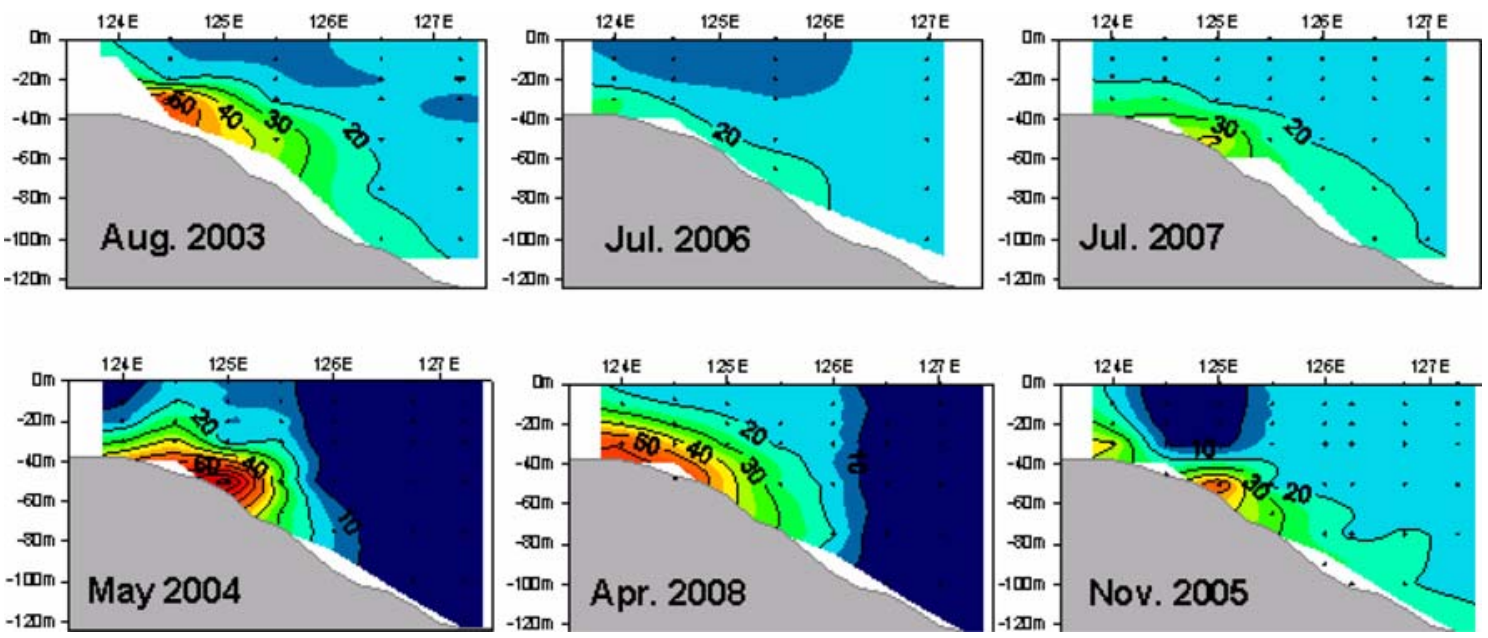

Fig. 4. Vertical distribution of suspended solids $\left(\mathrm{mg} l^{-1}\right)$ along the C-Line in the northern East China Sea from August 2003 to April 2008.
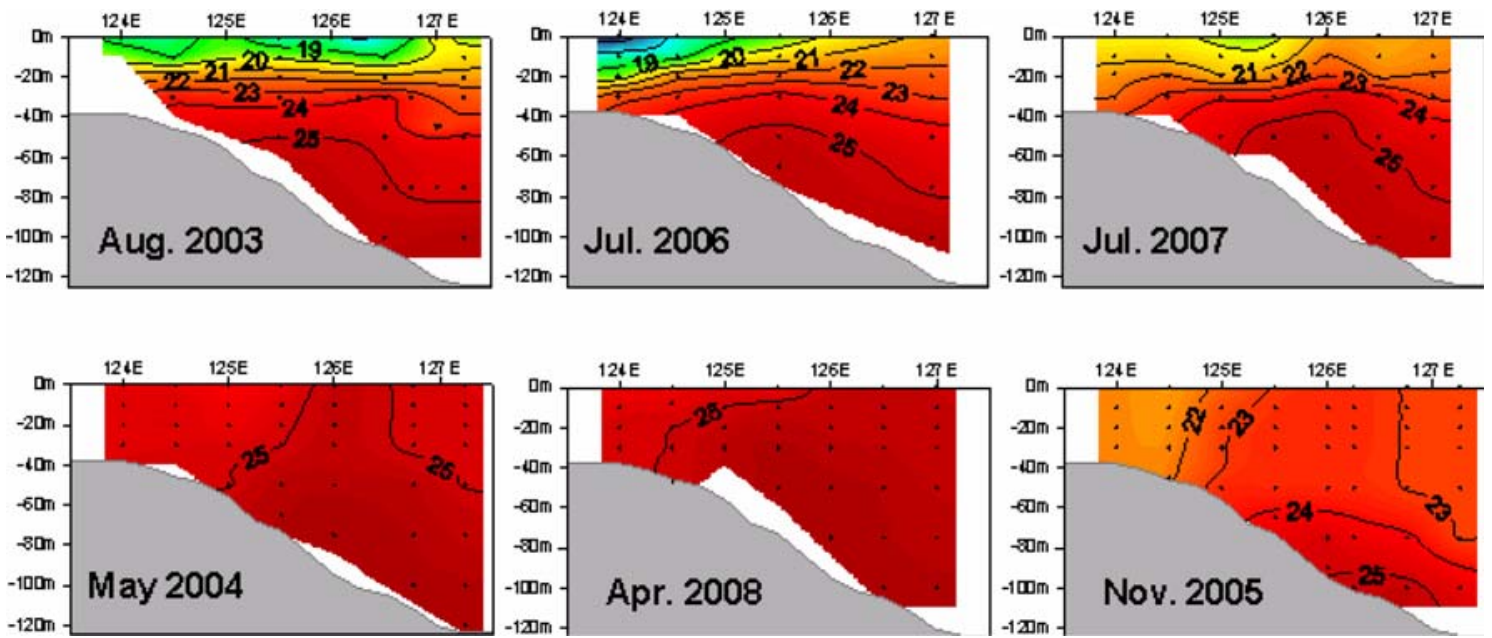

Fig. 5. Vertical distribution of water density along the C-Line in the northern East China Sea from August 2003 to April 2008.

로 여러 군데에 존재하였다. 표층 부유물질 분포에 있어서 가장 큰 계절변화의 특징은 여름에는 해역에 따라 농도 변화가 크지 않고 비교적 일정한 농도범위를 나타낸 반 면, 봄과 가을에는 해역에 따라 매우 큰 변화를 나타낸 것 이다.

Fig. 4는 연구해역에서 라인 $\mathrm{C}$ 를 따라 관측한 부유물질 의 수직분포를 보여준다. 2003년 여름에는 서쪽해역 저층 에서 $50 \mathrm{mg} l^{-1}$ 이상의 높은 부유물질 농도가 관측되었으 며, 부유물질 농도는 모든 해역에서 표층보다 저층에서 높 았다. 2006년과 2007년 여름에도 부유물질 농도가 표층에 서 낮고 수심에 따라 증가하였지만 2003년 여름과 같이 $50 \mathrm{mg} l^{-1}$ 이상의 높은 부유물질 농도는 관측되지 않았다. 저층에서 부유물질 농도가 높은 것은 저층류에 의해 저층 퇴적물이 재부유되었기 때문이다(Hoshika et al. 2003). 저 층 부유물질 농도가 특히 서쪽해역에서 높은 것은 서쪽해
역의 수심이 얕아서 저층류가 강하게 흐르기 때문이다. Fig. 5는 연구해역에서 라인 $\mathrm{C}$ 를 따라 관측한 해수 밀도의 수직분포를 보여준다. 여름에는 표층 수온이 높고 표층 염 분이 낮아 표층 $30 \sim 40 \mathrm{~m}$ 에서 성층이 강화된다. 여름에는 표층의 강한 성층화로 인해 저층류에 의해 재부유된 부유 물질이 표층으로 운반되지 않아 표층 부유물질 농도가 전 반적으로 $10 \sim 20 \mathrm{mg} l^{-1}$ 의 범위에서 일정하게 유지된다.

봄에는 저층에서 재부유된 부유물질 농도가 $60 \mathrm{mg} l^{-1}$ 이상으로 여름과 가을에 비해 월등히 높았다(Fig. 4). 봄에 저층에서 부유물질 농도가 가장 높은 것으로 보아 봄에 저층류의 유속이 가장 강할 것으로 생각된다. 봄에는 여름 과 달리 성층화가 강하게 발달하지 않아(Fig. 5), 저층에서 재부유된 부유물질이 표층에 운반되어 표층 부유물질 농 도가 서쪽해역에서 높게 관측되었다. 가을에도 저층에서 재부유된 부유물질이 표층에 운반되어 표층 부유물질 농 
도가 높게 관측되었다. 따라서 앞에서 표층 부유물질 분포 가 계절에 따라 큰 차이를 보이는 것은 표층해수의 성층 정도가 계절에 따라 달라 저층에서 재부유된 부유물질이 표층으로 운반되는 정도가 다르기 때문이다. 봄에 관측한 부유물질의 수직분포는 다른 계절과 매우 다른 양상을 나 타냈다. 동경 126도를 경계로 서쪽해역에서는 퇴적물의 재부유로 인해 부유물질 농도가 매우 높았고 수심에 따라 증가하는 반면, 동쪽해역에서는 재부유가 전혀 일어나지 않아 부유물질 농도가 수층 전체에서 $10 \mathrm{mg} \mathrm{l}$ - 이하로 매우 낮았고 수심에 따른 변화가 거의 없었다(Fig. 4). 봄 에는 저층류가 남-북 방향으로 흘러 열염분전선을 경계로 부유물질의 수직분포가 큰 차이를 보이는 것으로 생각된 다. 하지만 가을에 관측한 부유물질은 모든 해역의 저층에 서 높은 농도를 나타내, 봄과 전혀 다른 수직분포를 보였 다(Fig. 4). 이런 수직분포는 가을에는 저층류가 서-동 방 향으로 흘러 서쪽해역에서 재부유된 부유물질이 동쪽으로 이동되었기 때문이다. Hoshikra et al.(2003)는 동중국해에 서 저층류가 여름에는 남-북 방향으로 흐르고 가을에는 서-동 방향으로 흐른다고 보고하여, 위의 설명을 뒷받침해 준다.

\section{입자성유기탄소의 분포 및 계절변화}

동중국해 북부해역에서 관측한 표층 입자성유기탄소 농 도는 표층 부유물질과 달리, 계절에 따라 큰 차이를 나타 내지 않았다(Fig. 6). 여름에 관측한 표층 입자성유기탄소 농도는 대마난류의 영향을 받는 동쪽해역보다 장강에 인 접한 서쪽해역에서 높았다. 2007년에 관측한 표층 입자성
유기탄소의 평균농도는 $16.6 \mu \mathrm{mol} l^{-1}$ 로 가장 낮았고 2006년에는 $21.2 \mu \mathrm{mol} l^{-1}$ 으로 가장 높았다(Table 1). 표층 부유물질 농도는 2007년에 가장 높은 값을 보였지만 표층 입자성유기탄소 농도는 2007년에 가장 낮은 값을 나타냈 다. 봄에 관측한 표층 입자성유기탄소 농도는 남서해역에 서 높은 값들을 나타냈다. 2008년 봄에 관측한 표층 입자 성유기탄소의 평균 농도는 $23.8 \mu \mathrm{mol} l^{-1}$ 으로 2004년 봄 에 관측한 평균값 $\left(16.8 \mu \mathrm{mol} l^{-1}\right)$ 보다 다소 높았다(Table 1). 2005 년 가을에 관측한 표층 입자성유기탄소의 평균 농 도는 $17.4 \mu \mathrm{mol} l^{-1}$ 으로, 봄과 여름에 관측한 값들과 큰 차 이가 없었다. 부유물질 농도는 대체로 여름에 높았고 봄에 낮아, 계절적인 변화를 보인 반면, 입자성유기탄소 농도는 계절에 따라 큰 차이를 나타내지 않았다. 표층 입자성유기 탄소 농도는 여섯 차례 관측에서 표층 부유물질 농도와 아무런 상관관계를 보이지 않았다(Fig. 7). 이것은 표층 입 자성유기탄소 농도가 표층 부유물질에 의해 큰 영향을 받 지 않는 것을 지시해준다. 하지만 표층 입자성유기탄소 농 도는 여섯 차례 관측 모두에서 표층 엽록소 농도와 좋은 양의 상관관계를 나타냈다(Fig. 8). 결국, 표층 입자성유기 탄소 농도는 표층해수에 존재하는 식물플랑크톤 생물량에 의해 가장 큰 영향을 받는 것으로 판단된다.

Fig. 9는 연구해역에서 라인 $\mathrm{C}$ 를 따라 관측한 입자성유 기탄소의 수직분포를 보여준다. 입자성유기탄소의 수직분 포는 부유물질의 수직분포와 달리 계절에 따라 큰 차이를 나타내지 않았다. 여섯 차례 관측 모두에서 입자성유기탄 소의 수직분포는 열염분전선이 존재하는 동경 126 도를 경 계로 동쪽해역과 서쪽해역에 뚜렷한 차이를 보였다. 서쪽
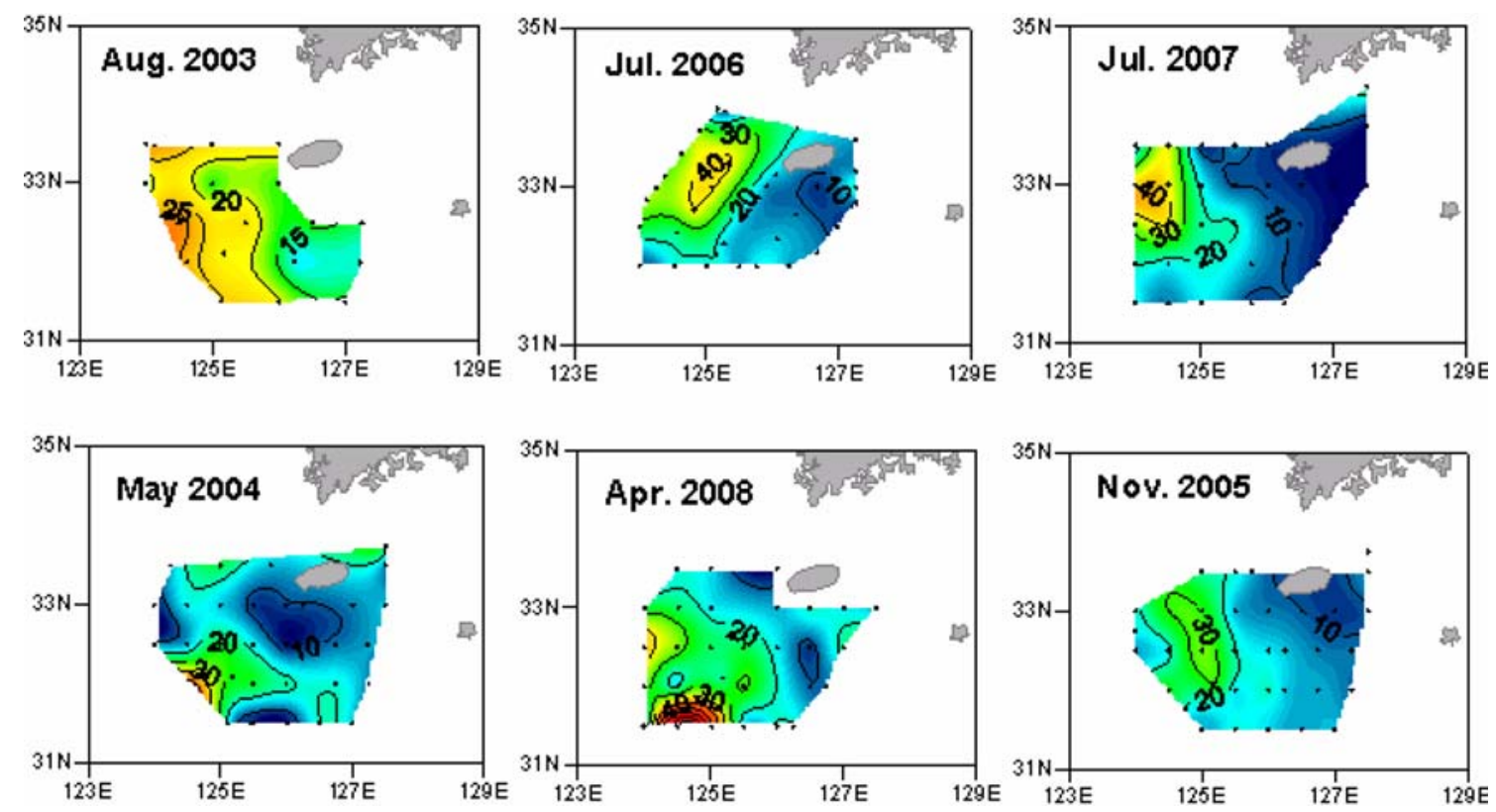

Fig. 6. Surface distribution of particulate organic carbon $\left(\mu \mathrm{mol} l^{-1}\right)$ in the northern East China Sea from August 2003 to April 2008. 

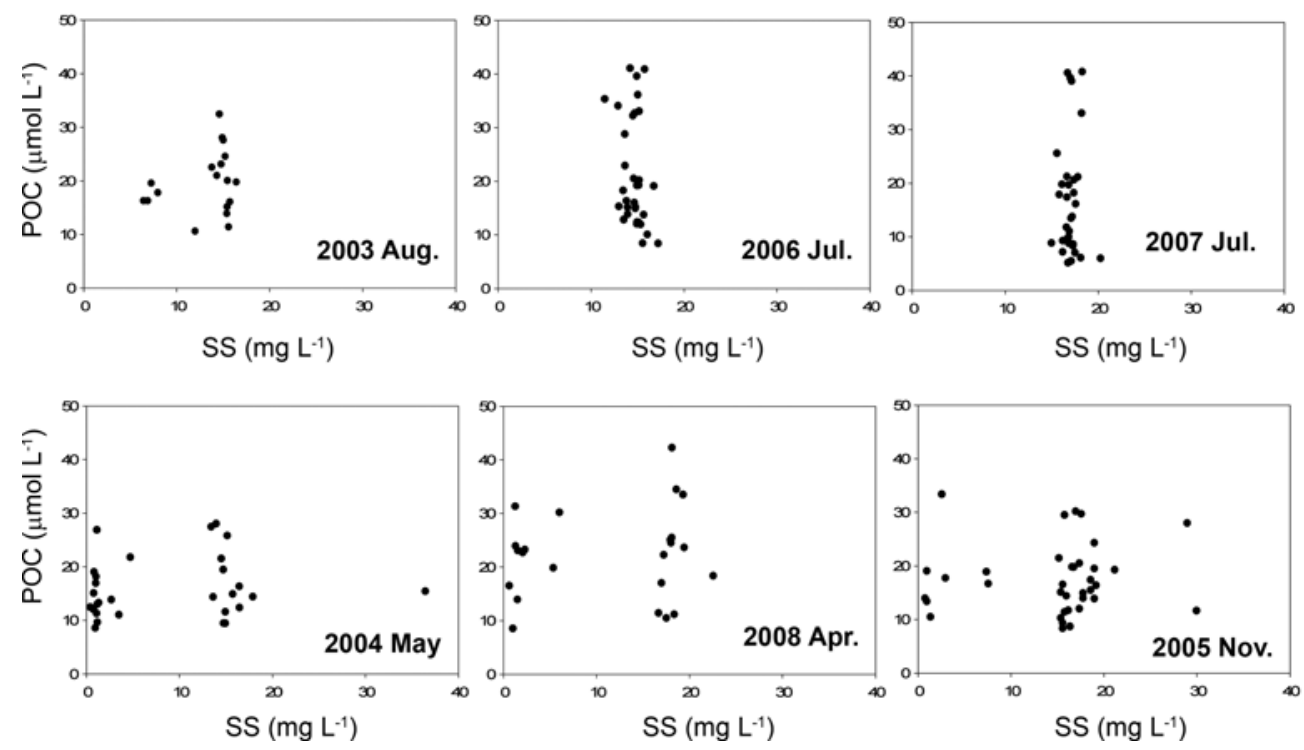

Fig. 7. Plots of suspended solids (SS) vs. particulate organic carbon (POC) in the surface waters from August 2003 to April 2008.
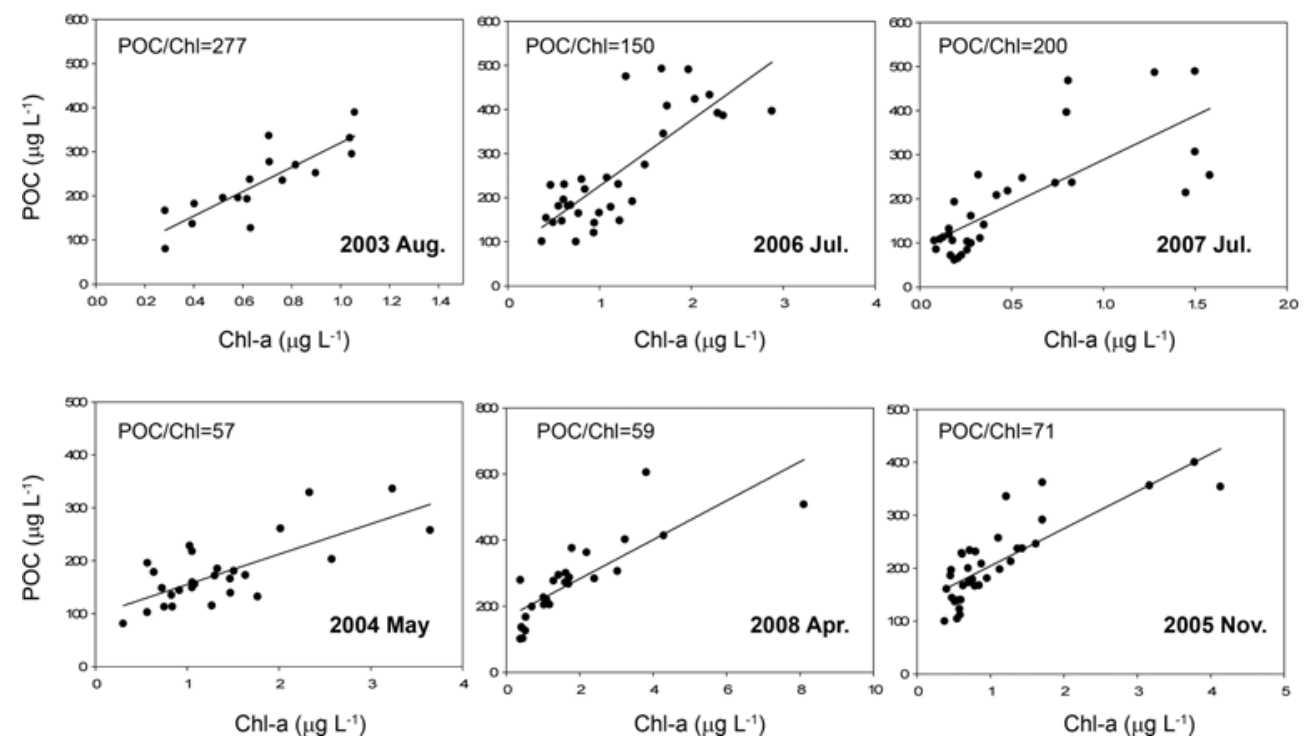

Fig. 8. Plots of chlorophyll- $a(\mathrm{Chl}-a)$ vs. particulate organic carbon (POC) in the surface waters from August 2003 to April 2008. POC/Chl ratio was obtained from the slope of the linear regression line.

해역에서는 입자성유기탄소 농도가 표층과 저층에서 상대 적으로 높은 반면, 동쪽해역에서는 수심에 따른 변화없이 전체적으로 낮았다. Fig. 8에서 표층해수에서 입자성유기 탄소 농도가 엽록소 농도와 좋은 양의 상관관계를 나타내 는 것으로 보아, 서쪽해역에서 표층 입자성유기탄소 농도 가 높은 것은 표층에 식물플랑크톤이 많이 서식하기 때문 이다. 또한, 저층에서 입자성유기탄소 농도가 높은 것은 강한 저층류에 의해 재부유된 부유물질이 많기 때문인 것 으로 판단된다. 이와 반대로, 동쪽해역 전체 수심에서 입 자성유기탄소 농도가 낮은 것은 표층에 서식하는 식물플
랑크톤 생물량도 적고 저층에서 재부유된 부유물질이 거 의 없기 때문이다. 표층에서는 식물플랑크톤 생물량이 저 층에 비해 많고 부유물질 농도 변화는 상대적으로 적기 때문에 입자성유기탄소 농도가 부유물질 농도에 의해 별 다른 영향을 받지 않았지만 저층에서는 재부유에 의해 부 유물질 농도가 높아, 입자성유기탄소 농도가 증가하였다.

\section{유기탄소/엽록소 및 유기탄소/질소 비율}

동중국해 북부해역의 여섯 차례 관측 모두에서 표층 입 자성유기탄소 농도는 표층 엽록소 농도와 상당히 좋은 양 

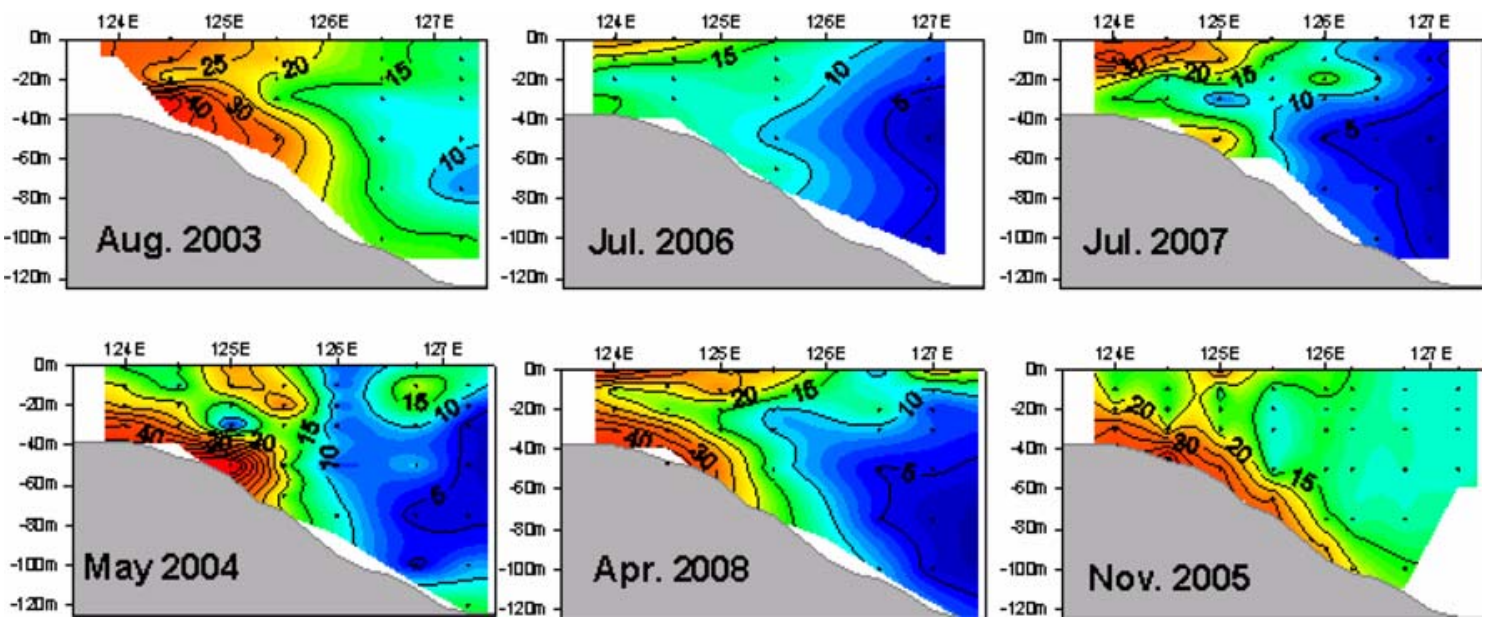

Fig. 9. Vertical distribution of particulate organic carbon $\left(\mu \mathrm{mol} l^{-1}\right)$ along the C-Line in the northern East China Sea from August 2003 to April 2008.

의 상관관계를 보였다(Fig. 8). 입자성유기탄소 농도와 엽 록소 농도의 기울기로부터 구한 유기탄소/엽록소 비율은 계절에 따라 매우 큰 차이를 나타냈다. 2003년, 2006년, 2007 년 여름에 관측한 유기탄소/엽록소 비율은 각각 277 , 150,200 으로 연도에 따라서도 큰 차이를 보였으며, 평균 은 209이었다. 2004년과 2008년 봄에 관측한 유기탄소/엽 록소 비율은 각각 57 과 59 로 매우 유사한 값들을 보였다. 2005년 가을에 관측한 유기탄소/엽록소 비율은 71로, 봄 에 관측한 값들과는 큰 차이를 보이지 않았지만 여름에 관측한 값들의 $1 / 3$ 밖에 되지 않았다. 해양생태계 연구에 있어서 식물플랑크톤의 생물량은 박테리아와 같은 다른 생물체의 생물량과 비교하기 위해서 유기탄소 함량으로 표시하는 것이 바람직하다. 하지만 식물플랑크톤의 유기 탄소 함량을 직접 측정하는 것은 매우 어렵다. 그대신, 측 정이 비교적 쉬운 엽록소 농도를 측정하여 식물플랑크톤 의 생물량을 나타낸다. 따라서 유기탄소/엽록소 비율은 식 물플랑크톤의 생물량을 엽록소 농도에서 유기탄소 함량으 로 전환하는데 매우 유용하게 이용된다. 실험실에서 배양 한 식물플랑크톤의 유기탄소/엽록소 비율은 광조건, 영양 염 농도, 수온에 따라 변하는데, 일반적으로 10100 의 범 위를 나타낸다(Cullen 1982; Geider 1993). 동중국해에서 관측한 유기탄소/엽록소 비율은 연안에서 13이었고 외양 에서 93이었다(Chang et al. 2003). 또한 북동 동중국해의 연안에서 관측한 유기탄소/엽록소 비율은 19 41의 범위를 나타냈다(Yamamoto 1995). 따라서 동중국해 북부해역에 서 봄과 가을에 관측한 유기탄소/엽록소 비율은 동중국해 에서 관측한 기존 연구결과와 유사하였지만 여름에 관측 한 비율은 기존 연구결과보다 월등히 높았다. 표층 유기탄 소 농도는 계절에 따라 큰 차이를 보이지 않고 100 500 $\mu \mathrm{g} l^{-1}$ 의 범위를 나타냈지만 표층 엽록소 농도는 여름에 비해 봄과 가을에 월등히 높았다(Fig. 8). 여름에 유기탄소/
엽록소 비율이 봄과 가을에 비해 높은 것은 유기탄소 농 도는 큰 차이가 없는데, 엽록소 농도가 봄과 가을에 비해 낮았기 때문이다. 엽록소는 살아있는 식물플랑크톤에서만 측정되지만, 유기탄소는 살아있거나 죽은 식물플랑크에서 도 측정된다. 여름에 유기탄소 농도는 봄과 가을과 유사하 지만 엽록소 농도가 월등히 낮은 것으로 보아 여름에 폐 사한 식물플랑크톤이 많은 것으로 판단된다. 여름에는 봄 과 가을에 비해 표층해수의 영양염 농도가 매우 낮기 때 문에 식물플랑크톤이 폐사할 가능성이 매우 높다. 따라서 여름에 유기탄소/엽록소 비율이 봄과 가을에 비해 높은 것 은 여름에 영양염 부족으로 인하여 식물플랑크톤이 폐사 하였기 때문인 것으로 판단된다.

표층 부유물질의 유기탄소 농도는 유기질소와도 상당히 좋은 양의 상관관계를 보였다(Fig. 10). 유기탄소 농도와 유기질소 농도의 기울기로부터 구한 유기탄소/질소 비율 도 유기탄소/엽록소 비율과 마찬가지로 계절에 따라 매우 큰 차이를 나타냈다. 세 차례 여름에 관측한 유기탄소/질 소 비율은 7.53 8.59의 범위를 보였고 평균 비율은 8.15 이 었다. 봄에 관측한 유기탄소/질소 비율은 5.95과 5.59이었 으며 가을에는 5.57 이었다. 봄에 관측한 유기탄소/질소 비 율은 가을에 관측한 값과 매우 유사하였으나 여름에 관측 한 값들보다는 상당히 낮았다. 식물플랑크톤의 유기탄소/ 질소 평균비율은 6.6이며 "Redfield ratio"라고 불린다 (Redfield et al. 1963). 봄과 가을에 관측한 유기탄소/질소 비율은 Redfield ratio보다 낮은 반면, 여름에 관측한 비율 은 높았다. 일반적으로 유기탄소의 분해속도가 유기질소 의 분해속도보다 느리기 때문에, 수심이 증가할수록 유기 탄소/질소 비율은 증가한다(Chester 2000). 따라서 여름에 관측한 유기탄소/질소 비율이 봄과 가을에 관측한 값들보 다 높은 것은 여름에 폐사한 식물플랑크톤이 많기 때문인 것으로 판단된다. 다른 가능성은 육상기원 유기물의 탄소/ 

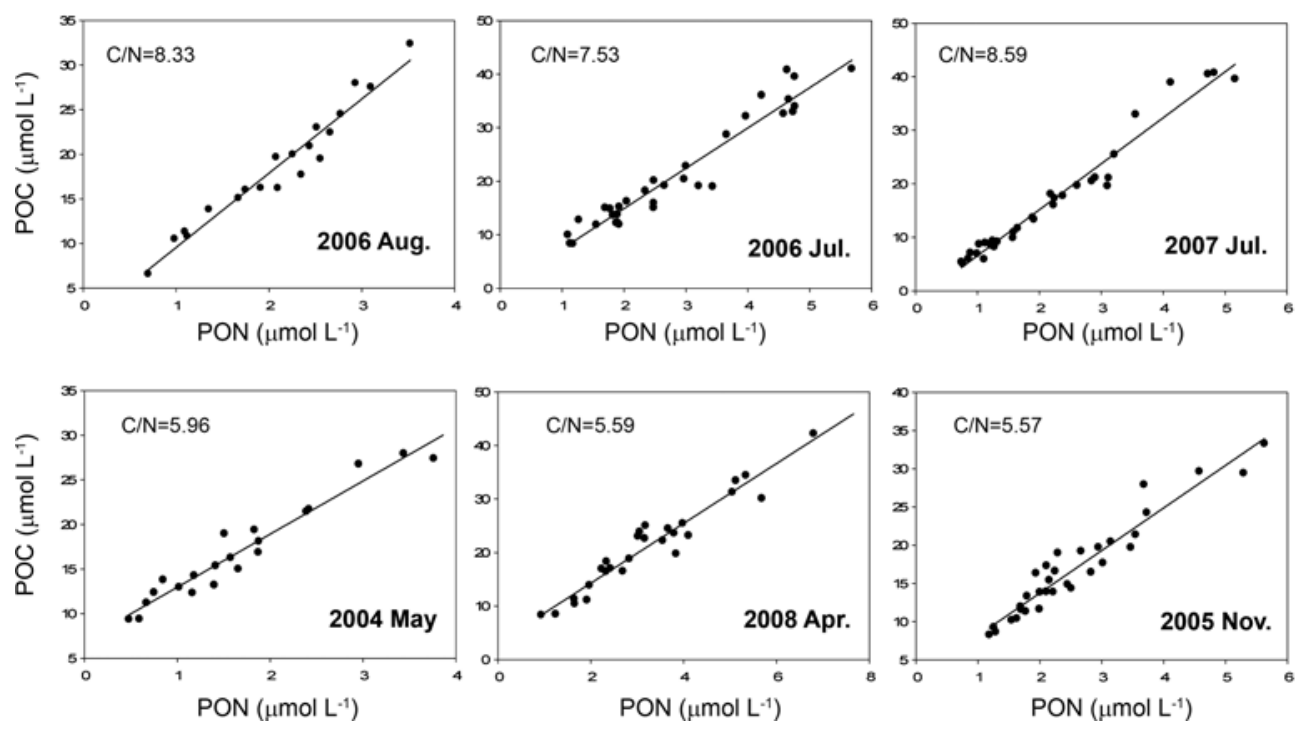

Fig. 10. Plots of particulate organic nitrogen (PON) vs. particulate organic carbon (POC) in the surface waters from August 2003 to April 2008. $\mathrm{C} / \mathrm{N}$ ratio was obtained from the slope of the linear regression line.

질소 비율은 20 이상으로 매우 높기 때문에(Meyers 1997), 여름에 육상기원 유기물이 본 연구해역으로 많이 유입되면 유기탄소/질소 비율이 봄과 가을에 비해 높게 된 다. 하지만 여름에 관측한 표층 부유물질과 입자성유기탄 소 농도가 봄과 가을에 비해 큰 차이가 없기 때문에, 여름 에 육상기원 유기물이 많이 유입되었을 가능성은 그다지 높지 않다.

\section{4. 결 론}

동중국해 북부해역에서 관측한 표층 부유물질 농도는 여름에는 해역에 따라 변화가 크지 않고 비교적 일정한 농도범위를 나타낸 반면, 봄과 가을에는 해역에 따라 매우 큰 변화를 나타냈다. 표층 부유물질 농도는 여름과 가을에 유사하였고 봄에는 여름과 가을에 비해 대체로 낮았다. 여 름에 장강을 통해 동중국해로 배출된 부유물질은 대부분 이 장강 인근해역에 퇴적되고 장강으로부터 $260 \mathrm{~km}$ 가량 떨어져있는 연구해역에는 도달하지 않았다. 부유물질 농 도는 저층에서 높게 관측되었는데, 이것은 저층류에 의해 저층퇴적물이 재부유되었기 때문이다. 표층 입자성유기탄 소 농도는 표층 부유물질과 달리, 계절에 따라 큰 차이를 나타내지 않았다. 표층 입자성유기탄소 농도는 표층 부유 물질에 의해 영향을 거의 받지 않고, 식물플랑크톤 생물량 에 의해 주로 영향을 받았다. 입자성유기탄소의 수직분포 는 열염분전선이 존재하는 동경 126 도를 경계로 동쪽해역 과 서쪽해역에서 뚜렷한 차이를 보였는데, 서쪽해역에서 는 입자성유기탄소 농도가 표층과 저층에서 상대적으로 높은 반면, 동쪽해역에서는 수심에 따른 변화없이 전체적
으로 낮았다. 유기탄소/엽록소 비율은 계절에 따라 매우 큰 차이를 나타내, 봄과 가을에 관측한 비율은 여름에 관 측한 비율의 $1 / 3$ 밖에 되지 않았다. 또한, 유기탄소/질소 비율도 계절에 따라 매우 큰 차이를 나타내, 봄과 가을에 관측한 비율은 Redfield ratio보다 낮은 반면, 여름에 관측 한 비율은 높았다. 여름에 관측한 유기탄소/엽록소 비율과 유기탄소/질소 비율이 봄과 가을에 비해 높은 것은 여름에 영양염 부족으로 인하여 식물플랑크톤이 폐사하였기 때문 이다.

\section{사 사}

본 연구에 많은 도움을 주신 연구선 이어도호 선장님과 승조원 여러분께 감사드립니다. 또한 현장조사에 많은 도 움을 주신 한국해양연구원 노재훈, 양은진, 최동한, 장성 태 박사님께도 진심으로 감사드립니다. 본 연구는 국토해 양부에서 지원한 “기후변화에 따른 남해(동중국해 북부) 의 해양환경 및 생태계 변동연구(PM54850)"와 한국해양 연구원의 일반사업인 “북서태평양이 한반도 주변해(대한 해협)에 미치는 영향 연구(PP00720)"의 일환으로 수행되 었습니다.

\section{참고문헌}

김동선, 김경희, 심정희, 유신재 (2007) 동중국해 북부해역에 서 여름동안 영양염, 엽록소, 부유물질의 분포 특성 및 연 간 변화. Ocean and Polar Res 29:193-204

Beardsley RC, Limeburner R, Yu H, Cannon GA (1985) 
Discharge of the Changjiang (Yangtze River) into the East China Sea. Continental Shelf Research 4:57-76

Carlson CA, Ducklow HW, Michaels AF (1994) Annual flux of organic carbon from the euphotic zone in the northwestern Sargasso Sea. Nature 371:405-408

Chang J, Shiah F-K, Gong G-G, Chiang KP (2003) Crossshelf variation in carbon-to-chlorophyll $a$ ratios in the East China Sea, summer 1998. Deep-Sea Res II, 50:1237-1247

Chen CTA, Ruo R, Pai SC, Liu CT, Wong GTF (1995) Exchange of water masses between the East China Sea and the Kuroshio off northeastern Taiwan. Cont Shelf Res 15:19-39

Chen CTA, Wang SL (1999) Carbon, alkalinity and nutrient budgets on the East China Sea continental shelf. J Geophys Res 104:20675-20686

Chester R (2000) Marine geochemistry, 2nd ed. Blackwell Science Ltd, Oxford, 506 p.

Cullen JJ (1982) The deep chlorophyll maximum: comparing vertical profiles of chlorophyll $a$. Canadian J Fish Aquatic Sci 39:791-803

Geider RJ (1993) Quantitative phytoplankton physiology: implications for primary production and phytoplankton growth. ICES Mar Sci Sym 197:52-62

Gong G-C, Chang J, Chiang K-P, Hsiung T-M, Hung C-C, Duan S-W, Codispoti LA (2006) Reduction of primary production and changing of nutrient ratio in the East China Sea: effect of the Three Gorges dam? Geophy Res Lett 33:LO7610

Hickox R, Belkin I, Cornillon P, Shan Z (2000) Climatology and seasonal variability of ocean fronts in the East China, Yellow and Bohai Seas from satellite SST data. Geophy Res Lett 27:2945-2948

Hoshika A, Tanimoto T, Mishima Y, Iseki K, Okamura K (2003) Variation of turbidity and particle transport in the bottom layer of the East China Sea. Deep-Sea Res II 50:443-455

$\mathrm{Hu}$ D (1994) Some striking features of circulation in Huanghai Sea and East China Sea. In: Zhou D, Liang YB, Zeng C-K (eds) Oceanology of China Seas, vol 1. Kluwar Academic, Norwell, pp 27-38

Humborg CV, Ittekkot AC, Bodungen BV (1997) Effect of Danube River dam on Black Sea biogeochemistry and ecosystem structure. Nature 386:385-388

Jiao N, Zhang Y, Zeng Y, Gardner W, Mishuonov V, Richardson M, Hong N, Pan D, Yan X-H, Jo Y-H, Chen CT, Wang P, Chen Y, Hong H, Bai Y, Chen X, Huang B, Deng H, Shi Y, Yang D (2007) Ecological anomalies in the East China Sea: impacts of the Three Gorges dam? Water Res 41:1287-1293

Kim D, Shim JH, Yoo S (2006) Seasonal variations in nutrients and chlorophyll-a concentrations in the northern East China Sea. Ocean Sci J 41:125-137

Kranck K, Milligan G (1992) Characteristics of suspended particles at an 11-hour anchor station in San Francisco Bay, California. J Geophy Res 97:11373-11382

Liu K-K, Gong G-C, Shyu C-Z, Pai S-C, Wei C-L, Chao SY (1992) Response of Kuroshio upwelling to the onset of the northeast monsoon in the sea north of Taiwan: observations and a numerical simulation. J Geophy Res 97:12511-12526

Liu K-K, Tang TY, Gong G-C, Chen YL, Shiah FK (2000) Cross-shelf and along-shelf nutrient fluxes derived from flow fields and chemical hydrography observed in the southern East China Sea off northern Taiwan. Cont Shelf Res 20:493-523

Matusike K, Okuda K, Uehara K (1983) Turbidity distribution near oceanic front in the coastal region of the East China Sea. La Mer 21:133-144

Meyers PA (1997) Organic geochemical proxies of paleoceanographic paleolimnologie, and paleoclimatic processes. Org Geochem 27:213-250

Milliman JD (1997) Blessed dam or damned dams? Nature 386:325-327

Milliman JD, Syvitski JPM (1992) Geomorphic/tectonic control of sediment discharge to the ocean: the importance of small mountainous rivers. J Geol 100:525544

Okamura K, Iseki K, Kiyomoto Y, Hoshika A, Tanimoto T (1997) Spring turbidity distribution on the shelf edge zone in the East China Sea. Umi no Kenkyu 6:361-369

Redfield AC, Ketchum BH, Richards FA (1963) The influence of organisms in the composition of seawater. In: Hill MN (ed) The sea. Interscience, New York, pp 26-77

Sanford LP (1993) New sedimentation, resuspension, and burial. Limnol Oceanogr 37:1164-1178

Sternberg RW, Larsen LH, Miao YT (1985) Tidally driven sediment transport on the East China Sea continental shelf. Cont Shelf Res 4:105-120

Su Y, Weng X (1994) Water masses in China Seas. In: Zhou D, Liang Y-B, Zeng CK (eds) Oceanography of China Seas. Kluwer Academic Publishers, Netherlands, pp 3-16

Tanaka K, Uno S, Sakamoto W, Shirota A (1987) Turbid water area in the East China Sea. Bull Nansei Regional National Fish Res Inst 64:13-23

Tian RC, Hu FX, Saliot A (1993) Biogeochemical processes controlling nutrients at the turbidity maximum and the 
plume water fronts in the Changjiang Estuary. Biogeochem 19:83-102

Tsai CH, Chen IJ (1996) Variability of suspended particle concentration due to tidal influences in the shelf sea north of Taiwan. La Mer 34:226-236

Walsh JJ (1991) Importance of continental margins in the marine biogeochemical cycling of carbon and nitrogen. Nature 350:53-55
Yamamoto T (1995) Contribution of micro- and nanophytoplankton cell carbon to particulate organic carbon in the East China Sea during May 1980. J Faculty Appl Biol Sci 34:147-160

Received Mar. 30, 2009

Revised May 13, 2009

Accepted Jun. 9, 2009 